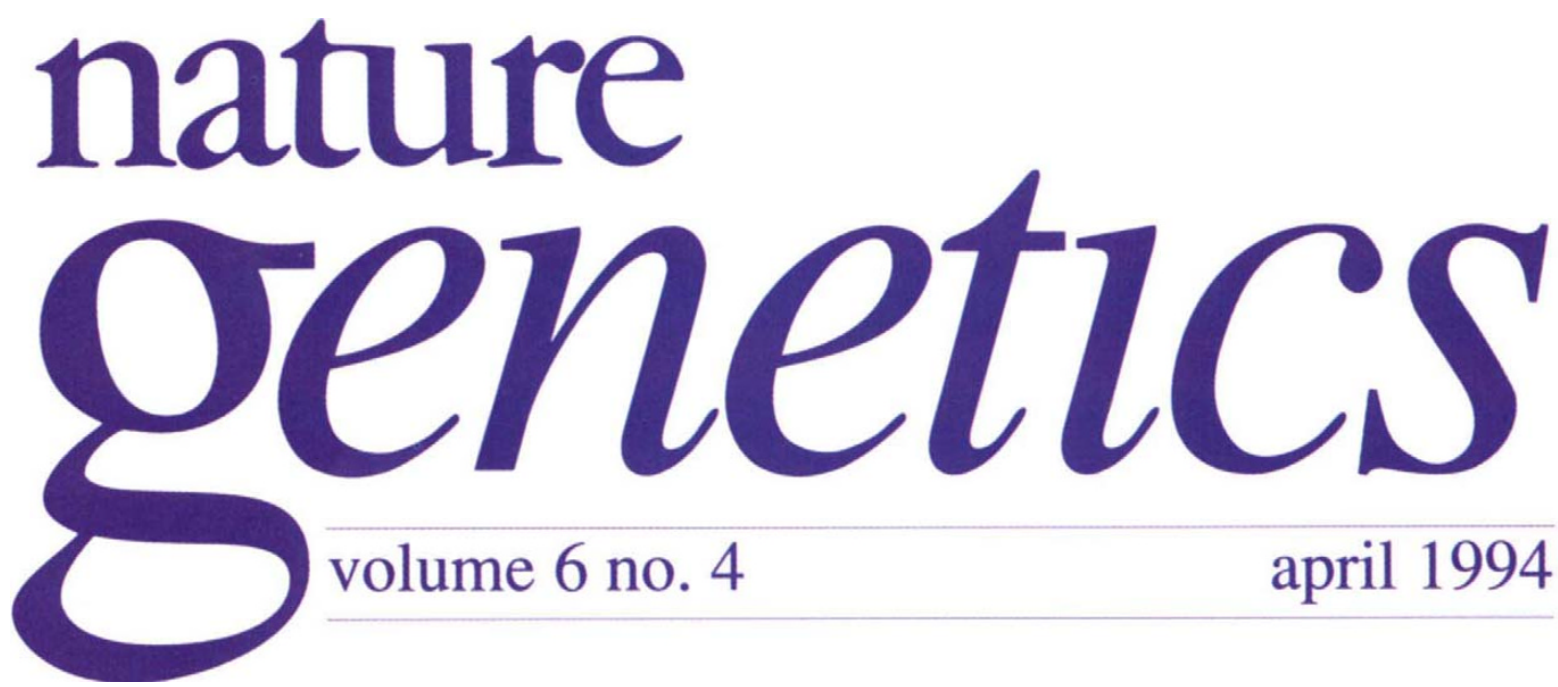

\title{
A small step for gene therapy
}

In June 1992, a 29-year-old woman from Quebec City in Canada with a rare but life-threatening form of hereditary heart disease underwent an historic operation at the University of Michigan Medical Center. Some 250 grams of the left lateral segment of her liver were removed and the tissue rushed on ice to a tissue culture laboratory. There, the hepatocytes were harvested into eight hundred $10 \mathrm{~cm}^{2}$ Petri dishes that required three separate incubators to house them all. After a couple of days, the cells were mixed with a retrovirus containing a normal copy of the human low-density lipoprotein receptor gene $(L D L R)$. After about $25 \%$ of the cells had taken up the virus, the hepatocytes were pooled and injected through a Hickman catheter previously inserted into the patient's mesenteric vein to deliver them back to her liver.

The patient, who is in the care of Dr James Wilson, suffers from familial hypercholesterolaemia $(\mathrm{FH})$, a rare but debilitating inherited disease in which serum levels of LDL-cholesterol rise to almost ten times normal. The first clinical manifestation is often sudden death. Wilson's patient is homozygous for a missense mutation in $L D L R$, which cripples the normal cholesterol scavenging function of the LDL receptor. She had a myocardial infarction at the age of 16 and had seen several brothers die from the disease. In fact, she is fortunate to have survived so long - most patients with $\mathrm{FH}$ do not survive much past the age of 25.
The concept of treating $\mathrm{FH}$ with ex vivo gene therapy crystallized with reports of the success of liver transplants for $\mathrm{FH}$ patients, and encouraging results from transferring $L D L R$ into Watanabe rabbits, a good model for FH. Fortunately for Wilson and his colleagues, including laboratory director Mariann Grossman and surgeon Steven Raper, the radical new procedure went well, and the patient's post-operative recovery was, in Wilson's terms, "satisfying", with only transient increases in portal hypertension. The operation was soon repeated in two other patients, both young children.

But the crucial question is whether such a major operation (at an estimated cost of $\$ 75,000$ ) has had the desired results. After 18 months of careful monitoring, the answer, reported on page 335 of this issue and discussed in an accompanying News \& Views (see page 325), seems to be a cautious 'yes'. There was no pathology apparent in a $50 \mathrm{mg}$ liver biopsy taken four months after the operation, and in situ hybridization with an antisense probe showed single cells expressing the gene. Most significantly, perhaps, the woman's LDL:HDLcholesterol ratio - a good indicator of coronary risk - has fallen from a range of $10-13$ to $5-8$, and although she is receiving levostatin to help to sustain this decrease, the first (and only) infusion of recombinant genes seems to be having the desired effect.

When Wilson presented his preliminary data on the first patient to the US Recombinant DNA Advisory Committee (RAC) in December 1992, he was swiftly granted approval to treat two more patients at the University of Pennsylvania (where 
his group has now established the Institute for Human Gene Therapy). One was a 41year-old woman, also from Quebec (where FH is six times more common than average) who underwent gene therapy a few months ago. The fifth patient, an 11-year-old girl, had the surgery last month.

The report from Grossman et al. represents the longest period of observation of a gene therapy patient published so far, although it was by no means the earliest approved gene therapy trial. That distinction, of course, went to Michael Blaese, Kenneth Culver and W. French Anderson of the National Institutes of Health (NIH), who treated four-year-old AshanthiDeSilva in September 1990 with modified $T$ lymphocytes containing the adenosine deaminase (ADA) gene to combat her severe inherited immunodeficiency. Both Ashanthi and the second patient treated by Blaese and colleagues four months later, 11-year-old Cynthia Cutshall, are said to be doing well. Cutshall has received treated stem cells in the hope of producing a more permanent correction of her defective immune system, and DeSilva is scheduled to be given the same.

Correcting the code. Despite the publicity given to the ADA trials, the results are only now being written up for a peer-review journal, partly because of the time necessary to evaluate the relative roles of the genetically modified cells and the PEGADA, which the patients still receive. But a comprehensive account of the events leading up

to that landmark experiment in September 1990, can be found in a new book written by Larry

\section{IMAGE UNAVAILABLE FOR COPYRIGHT REASONS}

Ashanthi

DeSilva, first recipient of the ADA gene.
Thompson, a journalist and television presenter, called Correcting the Code (Simon \& Schuster, New York; \$23). The book describes the events leading up to Ashanthi's treatment, focusing on the role of Anderson and his colleagues as they first countered setbacks in thelaboratory, and, later on, opposition in the RAC meetings, to launch the era of human gene therapy.

Although the ADA experiment was a landmark, the book succeeds best in describing the saga a decade earlier of Martin Cline, a physician at the University of California Los Angeles (UCLA) who, in 1980 , treated two very ill thalassaemia patients in Israel and Italy with recombinant $\beta$-globin genes, without winning prior approval from his review board. Thompson portrays a brilliant scientist who grew impatient with bureaucratic delays, and sought an easier passage to help treat critically ill patients with a revolutionary new therapy. After 14 months of deliberation, the UCLA review committee refused authorization of Cline's proposal to treat thalassaemics with human genes, the refusal fatefully coming one day after Cline had administered the globin genes to his second patient in Italy. Cline was never to see his patients again after the experiments. The patients themselves seemed to suffer no illeffects from the procedure, but in 1992 Ora Morduch, Cline's first patient, died from a bacterial infection at the age of 32 .

The only serious drawback of Correcting the Code is that it ends too soon. Anderson's difficulties in persuading the RAC to approve his trial are chronicled with precision, but the vital contribution of Claudio Bordignon - who successfully demonstrated the efficacy of ADA gene transfer in mice - in convincing the RAC rates only half a paragraph. There is only the briefest hint at the prospects for offering gene therapy to combat cancers and more common inherited diseases. Much more might have been said about the relative merits and deficiencies of liposomes and adenovirus vectors, and the immense difficulties that must be overcome in finding more practical forms of (in vivo) therapy.

Some might argue that gene therapy is far too immature a field to have earned such high-profile coverage already - even though the required technology has essentially been in place for 10 years. However, with recent opinion polls showing that the general public has a hopelessly naive impression of the capabilities and potential dangers of gene therapy, there is a serious need for thoughtful commentary on this burgeoning field. Most observers agree that the importance of the first gene therapy experiment was more cultural than scientific. With at least some ethical reservations regarding somatic gene therapy overcome, society is at last beginning to survey the clinical impact of gene therapy.

Nature Genetics volume 6 april 1994 